\title{
Is Misión Milagro an effective program to prevent blindness in Latin America?
}

\author{
Misión Milagro é um programa eficiente para a prevençâo da cegueira na América Latina?
}

João Marcello Furtado, Fabiano Cade, Van C. Lansingh, Andrea Zin, Carlos Eduardo Arieta, Jerónimo Fabiani, Cristián Luco, Serge Resnikoff

João Marcello Furtado, MD, PhD Vision 2020 International Fellowship - World Health Organization WHO - and International Agency for the Prevention of Blindness IAPB - Casey Eye Institute, Oregon Health and Science University. Portland, Oregon, USA.

Fabiano Cade, MD, MSc

Department of Ophthalmology, Federal University of São Paulo UNIFESP - São Paulo, Brazil.

Van C. Lansingh, MD, PhD Latin America Regional Director International Agency for the Prevention of Blindness - IAPB - Buenos Aires, Argentina.

Andrea Zin, MD, PhD Fernandes Figueira Institute, Department of Neonatology, Fiocruz. Rio de Janeiro, Brazil.

Carlos Eduardo Arieta, MD, PhD Associate Professor, Department Associate Professor, Department of Ophthalmology, Faculdade de Ciências Médicas da Universidade Estadual de Campinas UNICAMP - Campinas, Brazil. Jerónimo Fabiani IAPB Latin America, Buenos Aires, Argentina.

Cristián Luco, MD

President - Pan-American Association of Ophthalmology - PAAO and Fundación Oftalmológica Los Andes. Santiago, Chile.

Serge Resnikoff, MD, PhD Director for Advocacy - International Director for Advocacy- Internationa Council of Ophthalmology and $\mathrm{Co}-$ chair for Europe - International Agency for the Prevention of Blindn
IAPB - Geneva, Switzerland.
M isión Milagro ('Miracle Mission', in English) is the name given to the program established by the governments of Cuba and Venezuela to provide free ophthalmological assistance for poor people in Latin America and the Caribbean. The 'mission' was launched in 2004, when the first fifty surgeries were performed, and claims to promote the integration of the Latin American population (1), saving the sight of 6 million people in 10 years ${ }^{(2)}$. But its practices have been causing uncertainty in most ophthalmology societies in the region since its creation.

This program claims to provide free clinical and surgical ophthalmologic assistance covering 28 Latin American and Caribbean countries ${ }^{(3)}$. During the initial phase, the program was based in Cuba, with Venezuelan patients flown in for surgery accompanied by a care taker. After surgery, patients return to their home countries, and all of the expenses were paid initially by the Cuban and later the Venezuelan government ${ }^{(4)}$.

More recently, Venezuela has become the primary site for most of the surgery, with 74 medical centers around the country in which Cubans and Venezuelan doctors work together ${ }^{(5)}$. Apart from those in Cuba and Venezuela, there are 29 ophthalmological centers (mainly staffed by Cuban doctors) spread around at least 10 countries $^{(4)}$ in the region, and one in Angola ${ }^{(6)}$ that provide free clinical and surgical treatment for cataract, pterygium and other eye diseases to both local and foreign patients.

It is not clear how many patients have really been examined or treated by Misión Milagro since 2004. There are often contradictory reports in the literature, which are mostly from newspapers, about the number of patients treated. Most of those reports tend to be non-scientific and strongly focused on political propaganda.

As an example of conflicting data about the number of patients treated by the program, the official newspaper from the Venezuelan government published in July 2010 mentions that more than 900,000 patients (most of them Venezuelans) had received eye surgery in that country ${ }^{(7)}$. Yet, surprisingly, almost a year before, in October 2009, Venezuelan President Hugo Chávez had celebrated what he said was 1,000,000 surgical procedures performed by Misión Milagro in his nation ${ }^{(8)}$. From January to October 2010, approximately 157,000 patients received eye surgeries in the same country ( $98 \%$ of the patients being Venezuelan citizens). Intriguingly, only $20 \%$ of that total were said to have undergone cataract surgery ${ }^{(9)}$ in spite of that being the leading cause of blindness in Latin America ${ }^{(10)}$. The number of patients who had their sight restored must be even lower if we consider that: 1) some of these patients were likely to have had both eyes operated on; 2) not all were blind as defined by World Health Organization (WHO) (presenting Visual Acuity worse than 20/400 in the best eye) $)^{(11)}$; 3) some unknown and unreported number of them must presumably have had surgical complications or undetected co-morbidities.

Additionally, considering that the program is focused on surgical procedures, important issues of prevention of blindness may be not covered by Misión Milagro. It is not known if the screening and treatment of retinopathy of prematurity, a top priority in Latin America ${ }^{(12)}$, and the management of chronic diseases such as glaucoma and diabetic retinopathy are part of the program or not. Although its declared goal is to "preserve and promote" vision in 6 million people in the whole of Latin America and Caribbean (2) many surgeries done, for correction of strabismus or early stage pterygium in adults, actually don't have any impact on the prevention of blindness at all. So, it is unlikely that the 1 million surgeries reportedly done by Misión Milagro would in any case correspond to 1 million sight-restored patients.

Another factor to consider is that the presence of visiting ophthalmologists can destabilize local eye care services, especially if the work done during the visits are not based on a careful analysis of local needs and environment ${ }^{(13-14)}$. Of course, help from outside can be favorable for the community if key principles are followed, such as the use of appropriate techniques and equipment, frequent visits, devotion to transferring clinical and surgical skills to local practitioners, long-term and sustainable commitment encouraging the exchange of experience and ideas, involvement with local community, and always responding to local requests while strengthening local health systems to ensure long term sustainability ${ }^{(13)}$. Indeed, these principles apply to all visiting specialists, not only Misión Milagro. Unfortunately, Misión Milagro does not meet any of these criteria. 
By not fulfilling the criteria mentioned above, visiting Cuban doctors are usually not well accepted by medical societies ${ }^{(15-17)}$ nor by local citizens. In Venezuela, where a general health program began under the name "Misión Barrio Adentro", with the declared purpose of providing primary health care to the poorest Venezuelans, doctors report that the entry of Cuban doctors weakened their health system and created tension between foreign and local physicians ${ }^{(18)}$. Since there is an agreement permitting these foreign doctors to work in the country without a validated medical license, evaluation of the skills and quality of the visitors cannot be assessed, leaving the local population at risk, but with no possibility of holding the visitors accountable, and perhaps fueling a perceived high level of postoperative complications that must usually be handled by local ophthalmologists.

We should note that both the Pan-American Association of Ophthalmology (PAAO) and the International Agency for the Prevention of Blindness (IAPB) declared their opposition to the program quite a few years ago ${ }^{(19-20)}$, stating that Misión Milagro does not generally help develop local human resources and does not therefore strengthen local health systems, meaning that no sustainability is achieved by the program.

As an example of a different approach to the problem of blindness, the IAPB and WHO launched VISION 2020: The Right to Sight in 1999 for the purpose of eliminating avoidable blindness by the year 2020(21). To contribute to the achievement of the United Nations Millennium Development Goals(22), VISION 2020 advocates the implementation of self-sustaining and equitable eye-care services at the district level, stimulating the improvement of human resource and infrastructure ${ }^{(23-24)}$. This approach makes the development of ophthalmological services for long-term management of chronic eye diseases an imperative, since as life expectancy increases their burden on individuals and society increases as well. Ideally, the budget of a program should be planned and specified for years to come, as should the actions to be performed (including patient follow-up and the treatment of possible complications). Efficiency and quality must be monitored regularly to be sure that people are being helped and to help future program planners learn from them ${ }^{(24)}$, and local ophthalmology societies must be involved.

Implementing VISION 2020 principles depends on a strong partnership between PAHO (Pan-American Health Organization), the IAPB, the PAAO (the three founding members of VISION 2020; The Right to Sight Latin America), non-governmental organizations, national ophthalmology societies, international medical societies, as well as national and local/state governments. Thus, a five-year action plan for eye health is designed with a cascading process of adaptation from global to local ${ }^{(24)}$. Following such a road map could make Misión Milagro a true and welcome partner in development that strengthens local health systems and invests in improving local resources by operating on patients in their home countries, and that works in cooperation with the national prevention of blindness committees in areas decided on with aid of the local and national ophthalmology societies.

The best way to combat blindness worldwide is through development of integrated and self-sustainable eyecare services at the local and national levels, by improving the local ophthalmological services that will still be there to serve the people when the visitors go home. None of these things are being done by Misión Milagro.

\section{REFERENCES}

1. Red Popular Humanitaria Misioneros del Milagro [home page on the Internet]. $V$ enezuela: 2005. [cited 2010 Nov 8]: Available from: http://www.redmisionmilagro. org/objetivos.php

2. Garcia-Alcolea EE. [Origins of the Miracle Mission]. Arch Soc Esp Oftalmol. 2009;84(1): 51-2. Spanish.

3. Moreno Pérez LM, Peraza Martínez E, Figueiredo Valdéz R. La Misión Milagro: candil de esperanzas para América Latina. Rev Mission Milagro [Internet]. 2009 [cited 2010 Nov 8];3(1): Available from: http://www.misionmilagro.sld.cu/vol3no1/rev3102.php

4. Gorry C. Sight for Sore Eyes: Cuba's Vision Restoration Program. MEDICC Review [Internet] 2008 [cited 2010 Nov 8];10(2):49-51. Available from: http://www.medicc. org/mediccreview/articles/mr_37.pdf

5. Edwards E. Venezuela provides more than one million free eye operations to Latin Americans. Correo del Orinoco International. 2010 Aug 2. [cited 2010 Nov 8]. Available from: http://venezuelanalysis.com/news/5543

6. Operación Milagro con resultados relevantes en Jamaica y Angola. La Habana: Cuba debate; 2009 [cited 2010 Nov 9]; Available from: http://www.cubadebate.cu/ noticias/2009/12/24/operacion-milagro-resultados-relevantes-jamaica-angola//

7. Ellis E. The miracle of sight. Correo del Orinoco International [Internet]. 2010 Jul 30 [cited 2010 Nov 8]:22 [about 1p.]. Available from: http://www.correodelorinoco. gob.ve/wp-content/uploads/2010/07/Web-COl-22.pdf

8. Misión Milagro en Venezuela: un millón de intervenciones quirúrgicas gratuitas en cinco años. Cubadebate. Contra el terrorismo mediático [Internet]; 2010 Dic 2 [cited 2010 Dic 2]. Available from: http://www.cubadebate.cu/noticias/2009/10/23/ mision-milagro-en-venezuela-un-millon-de-intervenciones-quirurgicas-gratuitas-en-cinco-anos/.

9. Hospital Pérez Carreño de Caracas rompió récord de atención en Misión Milagro. Correo del Orinoco [Internet] 2010 Oct 2 [cited 2010 Nov 8]. Available from: http:// www.correodelorinoco.gob.ve/salud-publica/hospital-perez-carreno-caracasrompio-record-atencion-mision-milagro/

10. Limburg H, Silva JC, Foster A. Cataract in Latin America: findings from nine recent surveys. Rev Panam Salud Publica. 2009;25(5):449-55.

11. World Health Organization. International Statistical Classification of Diseases and Related Health Problems 10th Revision 2007. version for 2007 [Internet]. Genebra:
WHO; 2007. [cited 2010 Dec 1]. Available from: http://apps.who.int/classifications/ apps/icd/icd10online/

12. Gilbert C, Foster A. Childhood blindness in the context of VISION 2020-the right to sight. Bull World Health Organ. 2001;79(3):227-32

13. Pyott A. Short-term visits by eye care professionals: ensuring greater benefit to the host community. Community Eye Health. 2008;21 (68):62-3.

14. Pahau D, Brian G. Free cataract surgery may undermine local services in developing countries. Clin Experiment Ophthalmol. 2009;37(5):532-3.

15. Barría F. Misión Milagro: ¿Qué acciones debemos realizar? Rev Soc Chilena Oftalmol. 2006;11(107):4-5.

16. Consejo Argentino de Oftalmología. Malestar en Santiago del estero por "Misión milagro". Médico Oftalmólogo [Internet]. 2008 [cited 2010 Nov 8];21(5):20-1. Available from: http://www.oftalmologos.org.ar/cao_2010/publicaciones/mo/ archivos/mo21_5/mo21-5 santiago.pdf

17. AFP. Oftalmólogos uruguayos rechazan ejercicio de médicos cubanos en Montevideo. 2007 Nov 30. [cited 2008 Mar4 8]. Available from:http://afp. google.com/article/ALegM5jkazyAPflE9odrYzoOX7PTkIM-fw.

18. Cancel D. In Venezuela, two public-health systems grow apart. Lancet. 2007 11;370(9586):473-4

19. International Agency for the Prevention of Blindness [database on the Internet]. Asuncion: IAPB; 2005 [cited 2010 Nov 28]. Available from: http://www.v2020la.org/ images/Posicionamiento\%20_de\%20RD_.pdf.

20. Pan-American Association of Ophthalmology [database on the Internet]. Arlington Texas: 2006. [cited 2010Nov 28]. Available from: http://www.v2020la.org/images/ 2006_PAAOdeclarationENG.pdf.

21. Resnikoff S, Pascolini D, Etya'ale D, Kocur I, Pararajasegaram R, Pokharel GP, et al. Global data on visual impairment in the year 2002. Bull World Health Organ. 2004;82(11):844-51.

22. United Nations Millenium Development Goals [home page on Internet]. New York; 2010. [cited 2010 Nov 8]. Available from: http://www.un.org/millenniumgoals/.

23. Foster A, Resnikoff S. The impact of Vision 2020 on global blindness. Eye (Lond) 2005;19(10):1133-5.

24. V2020: The Right to Sight. Action plan 2006-2011 [Internet]. Geneva; World Health Organization; 2010. [cited 2010 Nov 8]. Available from: http://www.vision2020.org/ main.cfm?type=PUBLICATIONS 